\title{
Sistem Informasi Bimbingan Skripsi Menggunakan Metode Rapid Application Development Berbasis User Centered Design
}

\author{
Mochammad Alif Kurniawan, Iskandar Fitri*, Deny Hidayatullah \\ Fakultas Teknologi Komunikasi dan Informatika, Sistem Informasi, Universitas Nasional, Jakarta, Indonesia \\ Email: ${ }^{1}$ mochammadalifkurniawan@gmail.com, ${ }^{2, *}$ iskandar.fitri@civitas.unas.ac.id, ${ }^{3}$ deny @ civitas.unas.ac.id \\ Email Penulis Korespondensi: iskandar.fitri@ civitas.unas.ac.id
}

\begin{abstract}
Abstrak-Skripsi merupakan hasil karya tulis ilmiah penelitian yang ditulis dan disesuaikan dengan kaidah ilmiah yang berlaku dalam penulisan dan proses pengerjaan skripsi biasanya mahasiswa dibimbing oleh dua dosen pembimbing. Karena pada masa pandemi serta sulitnya berkonsultasi dengan dosen pembimbing dan ditetapkanya protokol kesehatan untuk menghindari dampak penyebaran virus COVID-19 penulis bermaksud untuk membangun aplikasi Sistem Informasi Bimbingan Skripsi yang dapat diakses secara daring dan berbasis website serta mempermudah proses pelaksaan skripsi. Fitur yang terdapat pada sistem tersebut diantaranya mahasiswa dapat mengajukan ide serta judul skripsi dan dapat melihat pemberitahuan ide serta judul skripsinya ditolak atau tidak. Mahasiswa yang melakukan skripsi dapat dipastikan diampu oleh dosen pembimbing oleh karena itu pembimbing dapat membina mahasiswanya menggunakan aplikasi tersebut dan dapat melaksanakan proses sidang serta seminar secara daring. Sistem informasi bimbingan skripsi dirancang menggunakan arsitektur Model View Controller yang memisahkan antar muka pengguna, data dan kontrol. Model pengembangan sistem berorientasi objek ini menggunakan model Unified Modeling Language yang bertujuan untuk menganalisa serta memodelkan aplikasi yang dirancang dengan menggunakan arsitektur berbasis Model View Controller. Metode pengembangan perangkat lunak yang digunakan pada pengembangan sistem ini adalah Rapid Application Development karenamemiliki fitur relatif sederhan. Pendekatan User Centered Design adalah pengguna dalam setiap tahapan pengembangan sistem juga terlibat, sehingga sistem yang dibentuk dapat digunakan sesuai dengan kebutuhan sistem.
\end{abstract}

Kata Kunci: Tugas Akhir Daring; Sistem Informasi; Bimbingan; Rapid Application Development; Tawk.to; User Centered Design

Abstract-Thesis is the result of a scientific research paper written and adapted to the scientific rules that apply in writing and the process of working on a thesis, usually students are guided by two supervisors. Because during the pandemic and the difficulty of consulting with supervisors and the establishment of health protocols to avoid the impact of the spread of the COVID-19 virus, the author intends to build a Thesis Guidance Information System application that can be accessed online and based on a website and facilitates the thesis implementation process. Features contained in the system include students who can submit ideas and thesis titles and can see notifications of ideas and thesis titles being rejected or not. Students who carry out theses can be ensured that they are supervised by their supervisors, therefore supervisors can guide their students using the application and can carry out online sessions and seminars. The thesis guidance information system is designed using the Model View Controller architecture which separates the user interface, data and control. This object-oriented system development model uses the Unified Modeling Language model which aims to analyze and model applications designed using Model View Controller-based architecture. The software development method used in the development of this system is Rapid Application Development because it has relatively simple features. The User Centered Design approach is that users in every stage of system development are also involved, so that the system formed can be used according to system needs.

Keywords: Online Final Project; Information System; Guidance; Rapid Application Development; Tawk.to; User Centered Design

\section{PENDAHULUAN}

Universitas Nasional selaku perguruan tinggi mempunyai tanggung jawab untuk mencetak mahasiswa yang berkompeten dan juga dapat bersaing di dunia kerja. Untuk mencetak mahasiswa yang berkompeten tentu dibutuhkan sarana dan prasarana yang mumpuni agar mahasiswa dapat produktif serta kreatif dalam proses belajar. SKS atau Sistem Kredit Siswa pada Universitas Nasional untuk tingkat Strata-1 memiliki beban belajar minimal bagi para mahasiswa untuk lulus dengan total 144 SKS. Mahasiswa dapat dikatakan lulus dalam mata perkuliahan jika mendapatkan nilai SKS minimal C. Syarat bagi mahasiswa untuk mendapatkan gelar Strata-1 adalah menyelesaikan skripsi dan memenuhi total 144 SKS tanpa ada mata kuliah yang mengulang serta memiliki sertifikat yang berhubungan dengan jurusan untuk menunjang kelulusan[1].

Dalam pelaksanaan skripsi mahasiswa harus melaksanakan bimbingan kepada dosen pembimbing untuk memberitahu dosen pembimbing proses yang sudah dicapai dari penulisan skripsi dan dosen pembimbing tersebut dapat mengoreksi kekurangan yang terdapat dalam skripsi yang telah dibuat mahasiswa[2]. Untuk berkonsultasi dengan dosen pembimbing seorang mahasiswa membutuhkan kartu konsultasi agar dapat menemui dosen pembimbing. Pada masa pandemi saat ini cukup sulit dalam melaksanakan bimbingan antara dosen dan mahasiswa dikarenakan kita harus menjaga jarak agar penyebaran virus COVID-19 dapat berkurang[3].

Untuk menyeleasikan masalah yang dihadapi oleh Universitas Nasional penulis membuat sistem yang berjudul "Sistem Informasi Bimbingan Skripsi Menggunakan Metode Rapid Application Development Berbasis User Centered Design". Pada sistem tersebut mahasiswa diharapkan menjadi tidak kesulitan dalam proses 
pengajuan ide skripsi karena proses tersebut dapat diakses oleh mahasiswa melalui website secara daring. Untuk berkonsultasi dengan sekretariat mahasiswa tugas akhir dapat menggunakan layanan live chat bernama Tawk.to yang tertanam pada sistem tersebut yang membuat mahasiswa tidak perlu datang kekampus pada era pandemi[4].

Dalam melakukan bimbingan secara teratur sebelumnya mahasiswa harus mendapatkan kartu konsultasi terlebih dari pihak sekretariat agar dapat melaksanakan bimbingan dengan dosen pembimbing, untuk penghematan kertas penulis membuat kartu konsultasi tersebut dapat diperoleh secara digital oleh mahasiswa tugas akhir melalui sistem bimbingan skripsi. Untuk mendapat informasi mengenai jadwal seminar ataupun sidang sebelumnya mahasiswa dapat melihat majalah dinding yang terdapat pada sekretariat, sekarang mahasiswa dapat melihat pemberitahuan tentang acara yang akan datang tentang seminar dan sidang pada akun mahasiswa[5].

Teknologi yang digunakan dalam pembangunan sistem informasi tersebut penulis menggunakan $P H P$ dengan kerangka kerja CodeIgniter sebagai bahasa pemrograman untuk sisi server[6]. Arsitektur pembangunan sistem berbasis website yang populer digunakan untuk pengembangan aplikasi adalah berbasis $M V C$ atau Model View Controller[7]. Cara kerja arsitektur MVC adalah model akan mengolah serta mencari informasi tersebut di dalam basis data, kemudian model memberikan kembali pada controller untuk ditampilkan hasilnya pada bagian view(tampilan), lalu controller mengambil hasil pengolahan yang dilakukan pada bagian model dan menatanya untuk view. Proses pertukaran data dan penampungan data yang terjadi pada sistem tersebut penulis menggunakan $M y S Q L$ sebagai DBMS karena mudah dikonfigurasi serta gratis untuk digunakan[8]. Dalam pemilihan metode pengembangan perangkat lunak penulis menggunakan metode Rapid Application Development, alasan menggunakan metode tersebut adalah sistem yang dibuat membutuhkan waktu yang cepat dan memiliki fitur yang relatif tidak terlalu kompleks dan banyak[9]. Metode desain sistem yang berfokus pada pengguna yakni User Centered Design diterapkan agar lebih berfokus pada pengguna[10].

Dalam penelitian ini penulis menggunakan jurnal lain yang membahas tentang sistem informasi bimbingan skripsi sebagai pembanding penelitian ini. Penelitian pertama membahas tentang monitoring bimbingan skripsi, penelitian tersebut menggunakan teknologi $P H P$ pada sisi server dengan kerangka CodeIgniter serta RDBMS untuk menampung basis data tersebut menggunakan $M y S Q L$, metode perancangan yang digunakan untuk aplikasi web tersebut adalah Waterfall dan dalam menganalisa data menggunakan kerangka kerja PIECES[11]. Penelitian kedua membahas tentang implementasi kerangka kerja CodeIgniter untuk bimbingan skripsi tersebut menggunakan RESTful-API untuk melakukan pertukaran data dan dalam penggunaannya menggunakan arsitektur Model View Controller[12]. Penelitan ketiga membahas tentang bagaimana android digunakan untuk merancan aplikasi e-skripsi serta metode yang digunakan untuk perancangan aplikasi tersebut adalah prototyping[13]. Penelitian keempat yang membahas tentang monitoring skripsi tersebut menggunakan pengujian Black Box untuk melakukan testing dan metode yang digunakan untuk melakukan pengembangan sistem bimbingan skripsi tersebut adalah $R A D$ yang merupakan akronim dari Rapid Application Development[14]. Penelitian terakhir yang penulis jadikan referensi untuk pengembangan sistem bimbingan skripsi membahas tentang bimbingan online berbasis website menggunakan metode pengembangan perangkat lunak air terjun atau waterfall dan teknologi yan untuk membangun sistem tersebut adalah $P H P$ dan $M y S Q L[15]$.

Beberapa referensi yang telah diambil oleh penelitian sebelumnya, penulis menjadikannya daftar acuan untuk pengembangan sistem. Tujuan dari pengembangan aplikasi tersebut adalah mempermudah mahasiswa dalam penyusunan skripsi dan membantu dosen untuk melakukan perbaikan atau revisi pada skripsi tiap mahasiswa yang mereka ampu. Aplikasi bimbingan skripsi mengutamakan efektifitas dan efesiensi dalam membantu mahasiswa dari segi waktu dan tempat dalam proses penyelesaian skripsi. Dengan adanya aplikasi bimbingan skripsi penulis berharap proses pelaksanaan skripsi mempermudah semua pihak yang terlibat dalam skripsi.

\section{METODOLOGI PENELITIAN}

\subsection{Kerangka Kerja Penelitian}

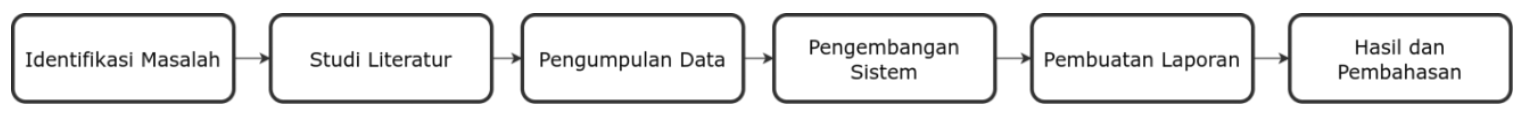

Gambar 1. Kerangka Kerja Penelitian

Dari gambar 1 kerangka kerja penelitian, dapat dijelaskan sebagai berikut:

\section{a. Identifikasi Masalah}

Pada tahapan pertama yaitu identifikasi masalah merupakan proses tahapan yang paling penting dan bertujuan untuk menguraikan serta menganalisa masalah yang nantinya akan menentukan kualitas dari penelitian. Mahasisa dan dosen akan mengadakan pertemuan dalam rangka bimbingan skripsi. Dikarenakan era pandemi ini harus mejaga jarak untuk mahasiswa yang ingin melaksanakan bimbingan, maka aktivitas 
bimbingan harus dilakukan secara daring.

b. Studi Literatur

Pada tahapan kedua yaitu studi literatur adalah memahami serta mempelajari teori yang masih relevan dan berhubungan terakit masalah yang akan nantinya diselesaikan. Teori yang relevan untuk memecahkan masalah tersebut kebanyakan berada diinternet dan berbagai sumber lain seperti buku, jurnal atau. Studi literatur dilakukan untuk mendapatkan pemahaman untuk pemecahan masalah yang nantinya akan diselesaikan.

\section{c. Pengumpulan Data}

Pada tahapan ketiga yaitu mengumpulkan data adalah tahapan mendapatkan data yang nantinya data tersebut akan diperlukan dalam melakukan penelitian. Metode yang digunakan dapat berupa pengamatan secara langsung kepada sistem atau melalui beberapa metode observasi lainnnya.

d. Pengembangan Sistem

Pada tahapan kelima adalah pengembangan perangkat lunak berbasis metode, metode yang digunakan adalah Rapid Application Development. Metode tesebut memiliki beberapa fase yaitu melakukan perencanaan kebutuhan, mendesain sistem, melakukan konstruksi serta implementasi.

\section{e. Pembuatan Laporan}

Pada tahapan kelima yaitu membuat laporan berbasil research yang berdasarkan dari penelitian yang telah dilakukan secara sistematis. Laporan berisi hasil analisis dari data yang telah dikumpulkan.

\section{f. Hasil dan Pembahasan}

Tahapan terakhir peneliti mendapatkan hasil dan pembahasa dari kegiatan yang sudah dianalisis pada tahap sebelumnya. Tahapan ini merupakan tahapan terakhir yang berada kerangka kerja penelitian.

\subsection{Metode Rapid Application Development}

Metodologi pengembangan pernagkat lunak dalam merancang sistem bimbingan skripsi adalah $R A D$ atau Rapid Application Development. Metode tersebut dikenal dengan metode yang dapat menghemat waktu pengembangan dikarenakan metode ini berfokus pada pengembangan sistem yang sangat cepat dengan pengulangan berbasis feedback yang terjadi secara terus menerus.

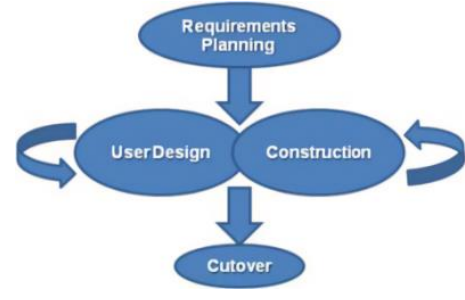

Gambar 2. Metode Rapid Application Development

Metode Rapid Application Development memiliki empat tahapan sebagai berikut:

a. Perencanaan Kebutuhan

Tahap perencanaan kebutuhan yang telah disesuaikan dan diperlukan untuk pengembangan sistem bimbingan skripsi dengan berbasis menggunakan metode Rapid Application Developer berbasis User Centered Design. Aktor yang terlibat dalam sistem tersebut ada 4 yaitu: Admin, Ka Prodi, Dosen, Mahasiswa. Metode Rapid Application Development sebagai metode pengembangan sistemnya. Sistem tersebut menggunakan kerangka kerja CodeIgniter sebagai bahasa sisi server unutk menangani sisi pengiriman dan kontrol data. Sedangkan untuk sisi klien atau yang menangani tampilan pada situs menggunakan Bootstrap. Dalam pemilihan basis data $M y S Q L$ sebagai $D B M S$ untuk menampung proses pertukaran dan kontrol akses dan manipulasi data pada sistem. Untuk mencetak kartu konsultasi library fpdf digunakan untuk mencetak dokumen. Layanan pihak ketiga berbasis Application Programming Interface bernama Tawk.to digunakan untuk memudahkan komunikasi antara admin dengan pengguna untuk keperluan aktivasi pengguna baru, perubahan hak akses dan lupa kata sandi. Kesimpulan dari tahap perencanaan kebutuhan adalah memilah serta memilih teknologi yang nantinya akan digunakan dalam pengembangan sistem.

b. Desain

Tahap desain atau pemodelan merupakan pembuatan aktor yang terlibat dalam sistem serta menunjukan perilaku dan fungsi yang dimiliki setiap aktor yang telah dibuat. Untuk memahami aksi dan fungsionalitas dari setiap aktor dibuatlah desain sistem berbasis diagram. Aktor yang telah ditentukan untuk desain sistem pada tahap perencaan adalah Admin, Ka Prodi, Dosen dan Mahasiswa karena menyesuaikan dengan kebutuhan sistem yang digunakan. Dalam mengetahui alur dari penggunaan sistem bimbingan skripsi dibuatkan Activity Diagram untuk menggambarkan bagaimana proses bimbingan skripsi dilakukan. Statechart Diagram menjelaskan bagaimana fitur tersebut dimiliki oleh aktor yang berada pada sistem. Kesimpulan dari tahap desain adalah penulis menggunakan Use Case Diagram untuk mengilustrasikan cara kerja dari setiap aktor yang terlibat. Acitivity Diagram menggambarkan bagaimana cara kerja suatu sistem 
dan Statechart Diagram menjelaskan bagaimana cara kerja fitur tersebut dimiliki oleh aktor yang terlibat.

\section{c. Konstruksi}

Tahap konstruksi atau eksekusi adalah tahapan pembuatan kode program yang mengacu pada diagram $U M L$ yang telah dibuat yaitu diagram Use Case, Activity dan Statechart pada tahap desain. Bahasa pemrograman yang digunakan pada sisi klien adalah HTML, Bootstrap dan JavaScript dan CodeIgniter pada sisi server. $M y S Q L$ digunakan untuk menampung basis data dan membuat pertukaran data pada sisi server. Kesimpulan dari tahap konstruksi adalah HTML, Bootstrap dan JavaScript digunakan pada sisi klien sedangkan CodeIgniter pada sisi server dan MySQL merupakan penghubungan antara pada bahasa pemrograman sisi server dengan basis data.

d. Implementasi

SImplementasi merupakan tahapan dari ketiga tahap yang sudah dilalui secara urut mulai dari tahap perencanaan kebutuhan, desain dan konstruksi. Tahap implementasi dapat dilakukan ketika tiga tahap tersebut berhasil dilalui, jika ada tahap yang belum terealisasikan dengan baik maka dapat mundur ketahap sebelumnya dan berulang terus hingga mendapatkan feedback berdasarkan sistem.

\subsection{User Centered Design}

\section{HASIL DAN PEMBAHASAN}

Dalam mendesain sistem Metode yang digunakan oleh penulis berbasis $U C D$ yang merupakan akronim dari User Centered Design. Fase yang terlibat dalam proses desain tersebut mengutamakan kebutuhan pengguna dapat terlihat pada gambar 3. Sistem yang dikembangkan dan menghasilkan produk perangkat lunak yang ramah pengguna dengan menggunakan metode tersebut untuk pengoptimalan dan keinginan suatu produk yang akan diberikan oleh end-user. Tahapan desain berbasis $U C D$ atau User Centered Design yang digunakan dalam desain sistem bimbingan skripsi ini adalah menggunakan perangkat lunak draw.io yang bersifat gratis dan mudah digunakan serta user-frinedly.

\subsection{Use Case Diagram}

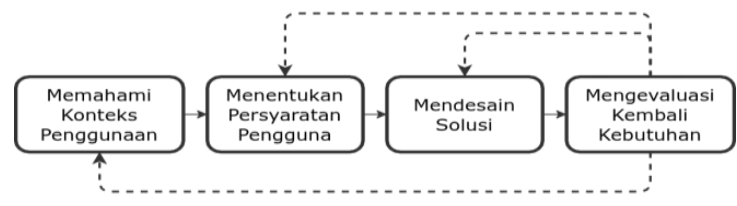

Gambar 3. User Centered Design

Diagram Use Case yang terdapat pada sistem tersebut adalah aktor admin dapat melakukan login, mengaktivasi mahasiswa yang sudah mendaftar melalui bimbingan skripsi dan ingin melakukan bimbingan skripsi. Mahasiswa tidak dapat login jika belum mendataftarkan diri pada sistem bimbingan skripsi, mahasiswa harus daftar terlebih dahulu menggunakan layanan live chat yang bernama Tawk.to agar admin dapat mengirimkan password kepada mahasiswa yang ingin melakukan bimbingan skripsi. Mahasiswa yang telah dapat login diharuskan mengaktivasi akunnya agar dapat lanjut ketahap pengajuan ide skripsi melalui layanan Tawk.to. Ka prodi selaku aktor yang berperan dalam sistem dapat mengkonfirmasi ide skripsi mahasiswa serta proposal dan skripsi mahasiswa. Ka prodi dapat merangkap sebagai dosen pembimbing satu dan menerapkan dosen pembimbing dua kepada mahasiswa yang melaksanakan bimbingan skripsi. Ka prodi dapat memberitakan kegiatan seminar dan sidang kepada mahasiswa yang melaksanakan bimbingan skripsi.

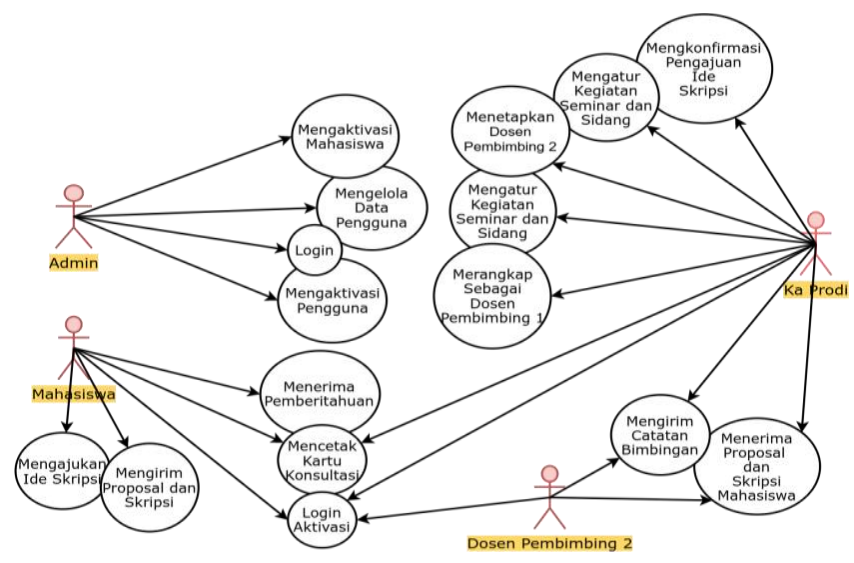

Gambar 4. Use Case Diagram

\subsection{Activity Diagram}

Mahasiswa mendaftar terlebih dahulu aplikasi bimbingan skripsi yang akan digunakan nantinya pada saat 
bimbingan. Mahasiswa yang akunnya sudah teraktivasi oleh admin dapat melakukan login, jika login berhasil dan akun tersebut sudah teraktivasi mahasiswa tersebut dapat mengajukan ide skripsi yang nantinya akan mendapat dua respon dari ka prodi yaitu diterima atau ditolak. Mahasiswa yang ide skripsinya ditolak dapat melanjutkan ketahap selanjutnya yaitu tahap bimbingan skripsi dan dosen pembimbingnya yang didapat oleh mahasiswa diterapkan oleh ka prodi. Saat proses bimbingan skripsi, mahasiswa menuliskan proposal dan skripsi yang nantinya akan dikoreksi oleh dosen pembimbing satu dan dua. Mahasiswa yang proposal dan skripsinya diterima dapat melaksanakan seminar dan sidang proposal.

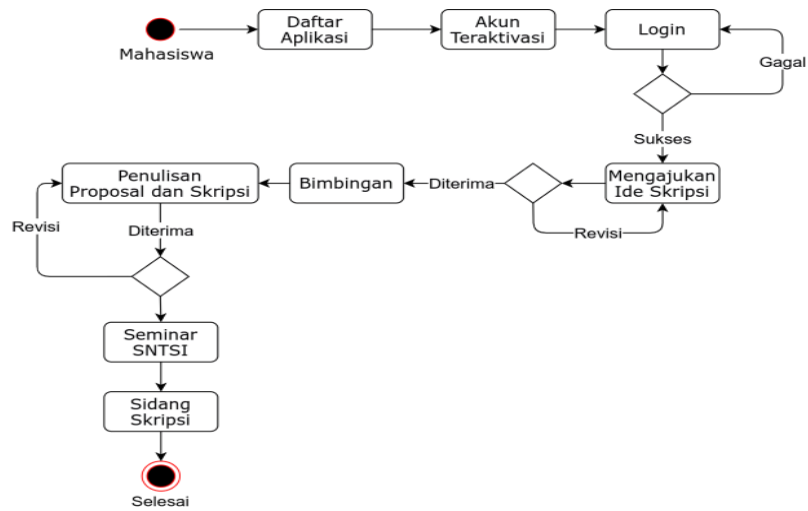

\subsection{Statechart Diagram}

Gambar 5. Activity Diagram

Pada Statechart diagram admin melakukan login, jika admin berhasil login maka admin dapat menggunakan aksesnya sebagai admin, fitur yang diperoleh oleh admin yang terutama adalah mengelola daa pengguna. Pengguna yang sangat berperan penting dalam proses bimbingan skripsi tersebut adalah mahasiswa dan dosen pembimbing. Admin akan mengirim password baru kepada mahasiswa yang telah mendaftar dan mengaktivasinya untuk dapat menggunakan fitur yang dapat mahasiswa akses. Admin dapat menginput data pengguna berupa mahasiswa, konsentrasi dan dosen.

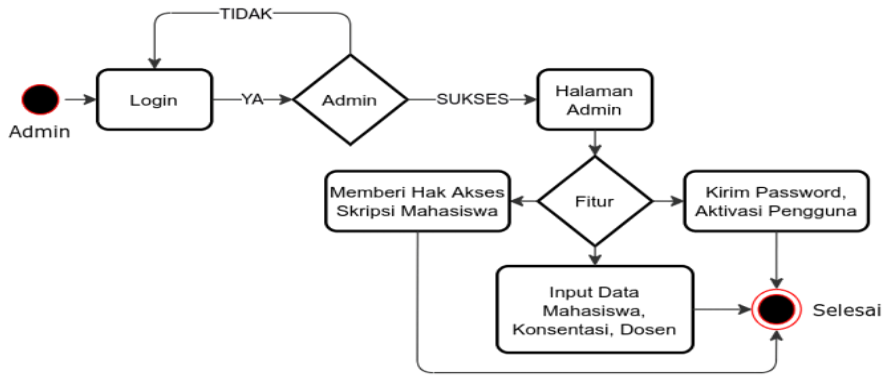

\subsection{Black Box Testing}

Gambar 6. Statechart Diagram

Setalah selesai melakukan pengembangan sistem bimbingan skripsi, aplikasi tersebut harus diuji dengan metode Black Box Testing untuk mengetahui apakah website yang telah kita buat berjalan dengan baik[16]. Pengujian menggunakan metode kotak hitam sangat mudah diuji karena tanpa harus melibatkan kode dari sistem yang akan diuji dan untuk menentukan hasil uji sesuai atau tidak hanya dengan menyesuaikan hipotesis yang telah dibuat atau tahap skenario pengujian.

Tabel 1. Skema Pengujian Kotak Hitam Aktor Admin

\begin{tabular}{clc}
\hline No & \multicolumn{1}{c}{ Skema Pengujian } & Hasil Uji \\
\hline 1 & Login Admin & OK \\
2 & Mengubah Data Profil Admin & OK \\
3 & Mengubah Status Mahasiswa dan Dosen & OK \\
4 & Menambah Data Konsentrasi & OK \\
5 & Mengirim Password Baru Kepada Pengguna & OK \\
6 & Mengaktivasi Pengguna & OK \\
8 & Logout Admin & OK \\
\hline
\end{tabular}

Pada tabel 1 terdapat skema pengujian dengan aktor admin yang akan menguji sistem pada hak akses admin, pengujian tersebut memiliki delapan tahapan dan akan diuji menggunakan metode Black Box. Mulai dari melakukan login sebagai admin dan dapat mengubah password jika diperlukan. Fitur utama admin yang 
membedakan dengan pengguna lainnya adalah tentang pengelolaan data. Admin dapat mengubah, menambah serta mengaktivasi status tiap pengguna baik mahasiswa, dosen dan ka prodi. Admin dapat mengirim password baru kepada penggunanya jika pengguna tersebut lupa akan password yang digunakan sebelumnya. Setelah semua fitur diuji, admin akhirnya dapat logout dari sistem sebagai aktor admin.

Tabel 2. Skema Pengujian Kotak Hitam Aktor Ka Prodi

\begin{tabular}{clc}
\hline No & \multicolumn{1}{c}{ Skema Pengujian } & Hasil Uji \\
\hline 1 & Login Ka Prodi & OK \\
2 & Mengubah Data Profil Ka Prodi & OK \\
3 & Memberitakan Kegiatan Seminar dan Sidang Skripsi & OK \\
4 & Melihat, Menerima dan Menolak Ide Skripsi Mahasiswa & OK \\
5 & Menerapkan Dosen Pembimbing Dua & OK \\
6 & Menyetujui Proposal dan Skripsi Mahasiswa & OK \\
7 & Memberikan Catatan Bimbingan & OK \\
8 & Mencetak Kartu Konsultasi & OK \\
9 & Logout Ka Prodi & OK \\
\hline
\end{tabular}

Pada tabel 2 terdapat skema pengujian dengan aktor ka prodi yang akan menguji sistem pada hak akses ka prodi, pengujian tersebut memiliki sembilan tahapan dan akan diuji menggunakan metode Black Box. Mulai dari melakukan login sebagai ka prodi dan mengubah password jika diperlukan. Pertama adalah ka prodi memasuki sistem sebagai aktor ka prodi dan dapat mengubah password jika diperlukan serta mengubah alamat email atau nomor telepon. Ka prodi dapat memberitakan kegitan mengenai acara terkait kegiatan seminar dan sidang skripsi yang akan datang. Ka prodi dapat melihat, menerima serta menolak ide skripsi mahasiswa. Ketika ide skripsi mahasiswa tersebut diterima oleh ka prodi, mahasiswa tersebut dapat melanjutkan ketahap selanjutnya yaitu penulisan proposal dan ka prodi dapat menerapkan dosen pembimbing dua untuk mahasiswa tersebut. Ka prodi dapat merangkap sebagai dosen pembimbing satu tiap mahasiswa yang akan diampunya serta dapat menyetujui proposal dan skripsi mahasiswa yang diampunya. Dalam melaksanakan bimbingan ka prodi dapat memberikan catatan untuk mahasiswa yang dibimbing serta dapat juga mencetak kartu konsultasi yang dimana nantinya akan digunakan untuk mahasiswa tersebut dalam proses konsultasi. Setelah semua fitur diuji, ka prodi akhirnya dapat logout dari sistem sebagai aktor ka prodi. Dari hasil akhir pengujian yang telah dilakukan sesuai dengan skenario pengujian tersebut, maka sistem ini sesuai dengan hasil yang diinginkan oleh penulis.

Tabel 3. Skema Pengujian Kotak Hitam Aktor Dosen

\begin{tabular}{clc}
\hline No & \multicolumn{1}{c}{ Skema Pengujian } & Hasil Uji \\
\hline 1 & Login Dosen & OK \\
3 & Mengubah Data Profil Dosen & OK \\
4 & Menyetujui Proposal dan Skripsi Mahasiswa & OK \\
6 & Memberikan Catatan Bimbingan & OK \\
7 & Mencetak Kartu Konsultasi & OK \\
8 & Logout Dosen & OK \\
\hline
\end{tabular}

Pada tabel 3 terdapat skema pengujian dengan aktor dosen yang akan menguji sistem pada hak akses dosen, pengujian tersebut memiliki delapan tahapan dan akan diuji menggunakan metode Black Box. Mulai dari melakukan login sebagai dosen dan mengubah password jika diperlukan. Pertama adalah dosen dapat memasuki sistem sebagai dosen dan dapat mengubah password jika diperlukan serta mengubah alamat email atau nomor telepon. Dosen dapat menyetujui proposal dan skripsi mahasiswa yang dibimbing dan dalam melaksanakan bimbingan dosen dapat memberikan catatan untuk mahasiswa yang dibimbing serta dapat juga mencetak kartu konsultasi yang dimana nantinya akan digunakan untuk mahasiswa tersebut dalam proses konsultasi. Setelah semua fitur diuji, dosen akhirnya dapat login dari sistem sebagai aktor dosen.

Tabel 4. Skema Pengujian Kotak Hitam Aktor Mahasiswa

\begin{tabular}{clc}
\hline No & \multicolumn{1}{c}{ Skema Pengujian } & Hasil Uji \\
\hline 1 & Login Mahasiswa & OK \\
2 & Mengubah Data Profil Mahasiswa & OK \\
3 & Mengajukan Ide Skripsi & OK \\
4 & Menerima Pemberitahuan & OK \\
5 & Mengupload Proposal dan Skripsi & OK \\
7 & Menerima Catatan Bimbingan & OK \\
8 & Mencetak Kartu Konsultasi & OK \\
9 & Logout Mahasiswa & OK \\
\hline
\end{tabular}


Pada tabel 4 terdapat skema pengujian dengan aktor mahasiswa yang akan menguji sistem pada hak akses mahasiswa, pengujian tersebut memiliki sembilan tahapan dan akan diuji menggunakan metode Black Box. Mulai dari melakukan login sebagai mahasiswa dan mengubah password jika diperlukan. Fitur-fitur yang terdapat pada mahasiswa mulai dari login hingga logout adalah mahasiswa dapat mengajukan ide skripsi dan terdapat dua kemungkinan saat proses pengajuan ide skripsi yaitu ide tersebut dapat ditolak atau diterima, jika ide skripsi diterima maka dapat dilanjutkan keproses penulisan proposal skripsi. Mahasiswa dapat mengupload proposal dan skripsi jika ide skripsinya diterima. Dalam pelaksanaan bimbingan mahasiswa dapat menerima pemberitahuan oleh dosen pembimbingnya serta dapat menerima catatan dan kartu bimbingan.

\subsection{Tampilan Antarmuka}

Pada setiap aplikasi berbasis website pasti memiliki antarmuka yang memiliki fungsionalitas utama yaitu memudahkan pengguna berinteraksi dengan sistem. Tampilan User Interface dari aplikasi sistem bimbingan skripsi yang telah dikembangkan menggunakan kerangka kerja CSS yaitu Bootstrap[17]. Tampilan antarmuka yang ditampilkan dalam sistem informasi bimbingan skripsi diantaranya adalah layanan Tawk.to yang bertujuan untuk melakukan komunikasi antara pihak yang terlibat proses pengerjaan skripsi dengan admin yang bertanggung jawab membalas pertanyaan serta keperluan pengguna. Tampilan antar muka lainnya melibatkan aktor yang terlibat dalam sistem tersebut adalah admin, ka prodi, dosen dan mahasiswa.

\subsubsection{Tawk.to}

Layanan live chat yang penulis pilih adalah Tawk.to karena layanan tersebut bersifat gratis, mudah dikonfigurasi serta sangat ramah pengguna dari segi penggunaan baik dari User Interface dan User Experience. Tampilan yang menarik dan kemudahan dalam penggunaan layanan live chat tersebut membuat pengguna tidak kesulitan dalam penggunaan aplikasi Tawk.to. Aktor utama yang dapat berinteraksi dengan admin adalah mahasiswyang bertujuan untuk mempermudah proses pendaftarakan akun, aktivasi pengguna hingga lupa kata sandi dapat dikonsultasikan langsung dengan admin melalui layanan Tawk.to.

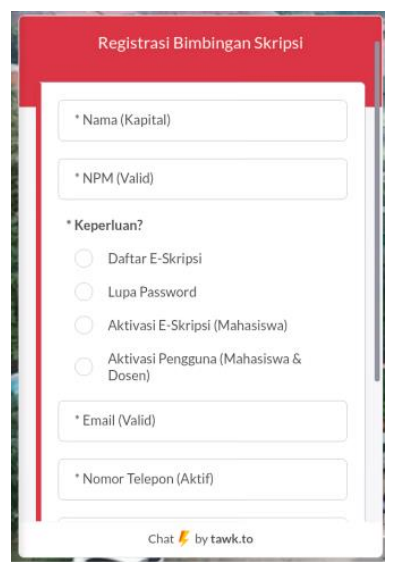

Gambar 7. Tawk.To

\subsubsection{Halaman Admin}

Halaman admin terdiri dari berbagai halaman yaitu beranda, data mahasiwa, dosen dan pengaturan. Aktor admin bertujuan untuk mengelola data pengguna mulai dari penambahan akun yang akan terlibhat dalam sistem skripsi nantinya, hak akses yang diberikan untuk mahasiswa yang ingin skripsi serta fitur lupa password untuk mengirim kembali password yang baru kepada pengguna.

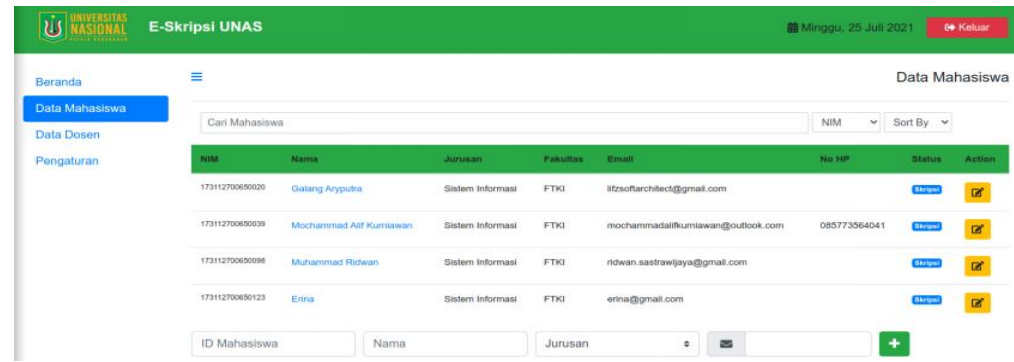

Gambar 8. Tampilan Halaman Admin

\subsubsection{Halaman Ka Prodi}

Halaman ka prodi terdiri dari pemberitahuan, ide skripsi, skripsi dan kegiatan. Ka prodi dapat menyetujui dan 
menolak ide tiap skripsi mahasiswa dan memberikan catatan tentang ide pengajuan skripsi tersebut ditolak. Ka prodi dapat menyetujui proposal dan skripsi mahasiswa tersebut. Ka prodi dapat merangkap sebagai dosen pembimbing satu. Kaprodi dapat memberikan catatan serta penulisan proposal dan skripsi kepada mahasiswa bimbingannya dan mencetak kartu konsultasi dari mahasiswa yang diampu. Ka prodi juga dapat mengirim pemberitahuan tentang kegiatan sidang proposal dan seminar diwaktu mendatang.

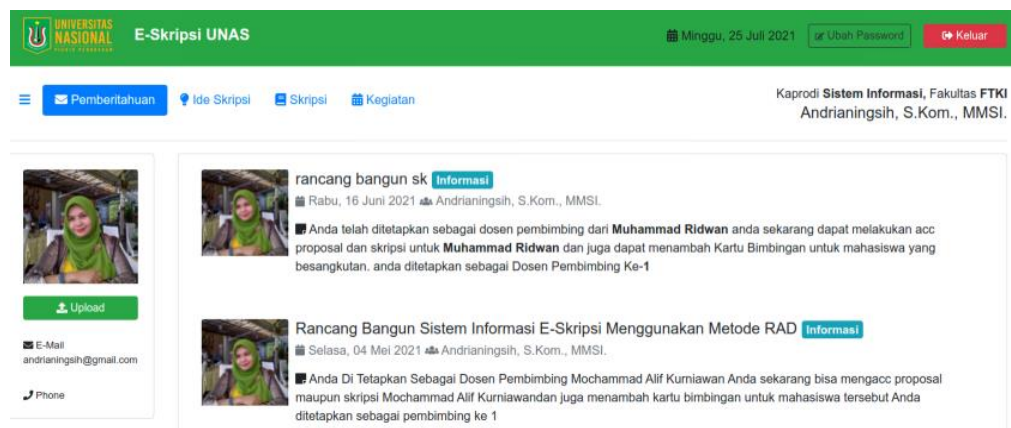

Gambar 9. Halaman Utama Ka Prodi

\subsubsection{Halaman Dosen Pembimbing}

Halaman dosen pembimbing satu terdiri dari pemberitahuan dan skripsi. Umumnya pada pelaksanaan bimbingan setiap mahaiswa diampu oleh dua dosen pembimbing. Ka prodi dapat merangkap sebagai dosen pembimbing satu dan menerapkan dosen lain yang melakasanakan proses bimbingan menjadi dosen pembimbing dua. Dosen pembimbing satu dapat diampu oleh Profesor ketika ka prodi sudah mencukupi nilai maksimum untuk mahasiswa bimbingannya. Dosen pembimbing dua dapat menyetujui serta menolak proposal dan skripsi tiap mahasiswa yang diampunya serta memberikan catatan pada penulisan proposal dan skripsi yang mahasiswa kirim. Dosen pembimbing dua memiliki akses yang terbatas, dosen pembimbing dua tidak dapat menerima dan menolak ide skripsi mahasiswa, memberikan pemberitahuan dan mengatur jadwal sidang skripsi dan kegitatan seminar seperti ka prodi.

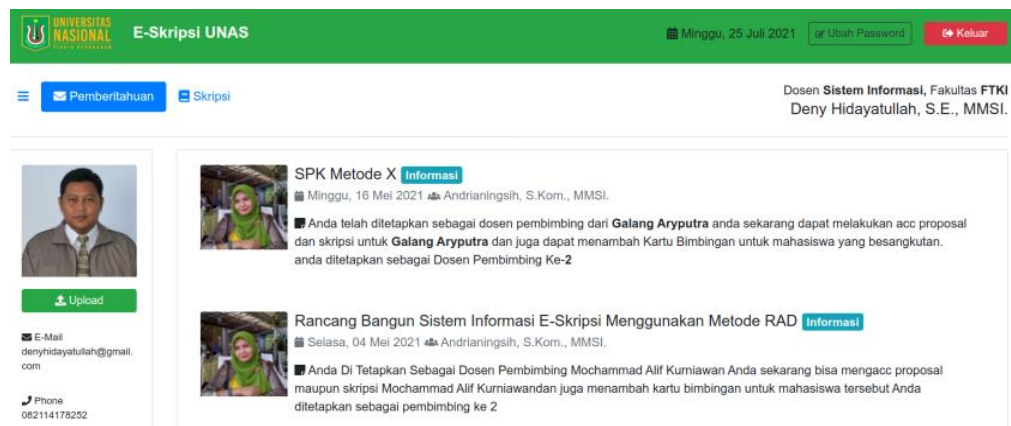

Gambar 10. Halaman Utama Dosen Pembimbing

\subsubsection{Halaman Mahasiswa}

Halaman mahasiswa terdiri dari pemberitahuan, ide skripsi dan skripsi. Setelah mahasiswa mengaktivasi akunnya menjadi status skripsi, mahasiswa tersebut dapat mengajukan ide skripsi yang nantinya akan disetujui oleh ka prodi. Jika ide pengajuan skripsi tersebut diterima oleh ka prodi, halaman ide skripsi tersebut akan hilang dan berubah menjadi skripsi setelahnya mahasiswa dapat mengunggah dokumen mengenai proposal dan skripsi. Mahasiswa dapat menerima pemberitahuan oleh ka prodi mengenai seminar dan sidang.

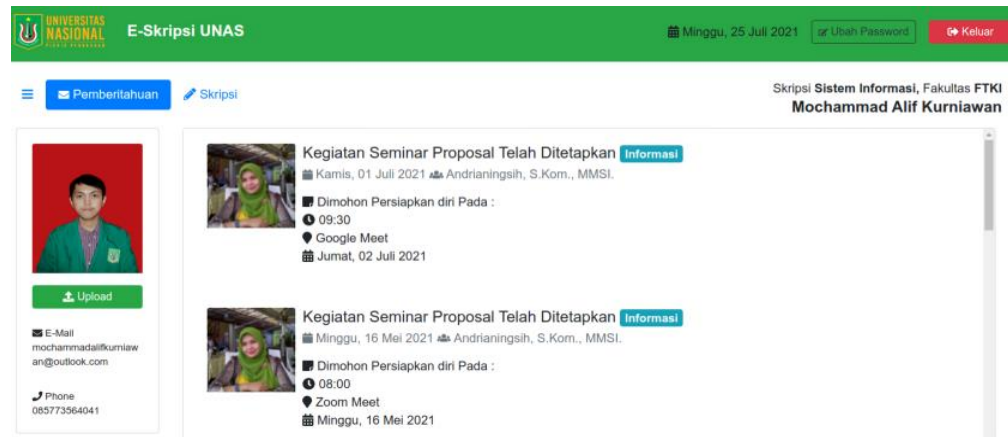

Gambar 11. Halaman Utama Mahasiswa 


\subsubsection{Kartu Konsultasi}

Kartu konsultasi membuktikan bahwa mahasiswa tersebut telah melakukan konsultasi dengan dosen pembimbing yang mahasiswa tersebut ampu. Mahasiswa dapat mencetak kartu konsultasi tersebut pada setiap akun mahasiswa yang sedang melakasanakan bimbingan skripsi. Bentuk kartu konsultasi yang dicetak oleh sistem bimbingan skripsi berformat $p d f$.

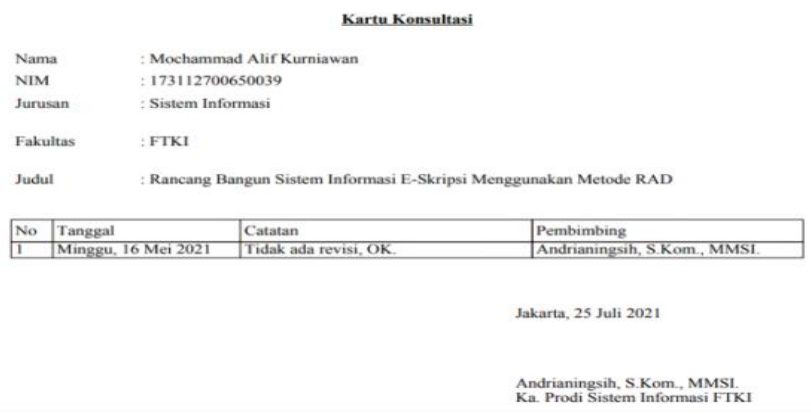

Gambar 12. Kartu Konsultasi

\section{KESIMPULAN}

Hasil penelitian yang dilakukan oleh penulis mengenai Sistem Informasi Bimbingan Skripsi yang menggunakan kerangka kerja $P H P$ yaitu CodeIgniter dan basis data $M y S Q L$ tidak ditemukan kendala yang pada saat pengujian menggunakan metode Black Box. Aplikasi tersebut sifatnya Cross Platfrom yang berarti dapat dijalankan pada semua sistem operasi dan mengandalkan peramban yang umum digunakan seperti Google Chrome, Firefox, Opera, Safari dan lain lain. Berdasarkan hasil dan implementasi serta pengujian dapat disimpulkan bahwa aplikasi tersebut mampu memberikan kemudahan kepada mahasiswa dengan dosen pembimbingnya dalam proses bimbingan tugas akhir tanpa harus dibatasi oleh jarak dan waktu. Memudahkan dosen pembimbing dalam memberikan pengumuman kepada mahasiswanya secara daring membuat mahasiswanya tidak akan tertinggal informasi mengenai tugas akhir. Mahasiswa dapat mengetahui pemberitahuan tentang seminar dan sidang skripsi secara terjadwal yang dikirimkan oleh ka prodi untuk mahasiwa yang bersangkutan tanpa perlu takut ketinggalan informasi tentang acara yang akan diadakan dalam waktu dekat. Dosen pembimbing dapat dipermudah dalam memberikan persetujuan atas pengajuan ide skripsi, proposal dan skripsi dari mahasiswa dan memberitahu langsung kepada mahasiswa bimbingannya melalui sistem. Tawk.to sebagai obrolan yang sifatnya live mempermudah pengguna untuk melakukan konsultasi terkait pendaftaran aplikasi, lupa password, aktivasi mahasiswa, serta aktivasi pengguna baru untuk mahasiswa dan dosen. Terakhir adalah dapat menghemat biaya pengeluaran fakultas untuk kertas yang digunakan untuk mencetak kartu konsultasi yang digunakan mahasiswa tersebut untuk melaksanakan bimbingan tugas akhir.

\section{REFERENCES}

[1] M. Rizki Shofiyulloh, A. Teguh Wibowo, and F. Muslihul Amin, "Rancang Bangun Sistem Informasi Pelayanan Skripsi untuk Mendukung Layanan Akademik," NJCA (Nusantara J. Comput. Its Appl., vol. 5, no. 1, pp. 8-15, 2020.

[2] R. A. Krisdiawan, "Rancang Bangun Sistem Informasi Judul Dan Pembimbing Skripsi /Tugas Akhir Fkom Uniku," Buffer Inform., vol. 3, no. 1, pp. 1-8, 2018, doi: 10.25134/buffer.v4i1.1135.

[3] Firman and S. R. Rahman, "Pembelajaran Online di Tengah Pandemi Covid-19 Firman1, Sari Rahayu Rahman1," Indones. J. Educ. Sci., vol. 2, no. 2, pp. 81-89, 2020.

[4] E. Febriyanto, N. S. R. Rais, and F. Syafaah, "Penerapan Aplikasi Tawk To IduHelp! Sebagai Sarana Pelayanan Informasi di Perguruan Tinggi," Technomedia J., vol. 3, no. 2, pp. 246-259, 2019, doi: 10.33050/tmj.v3i2.850.

[5] M. A. Dewi and R. Irham, "Penerapan Agile Scrum Pada Pengembangan Bimbingan Daring Skripsi Mahasiswa," J. SISKOM-KB (Sistem Komput. dan Kecerdasan Buatan), vol. 4, no. 2, pp. 40-45, 2021, doi: 10.47970/siskomkb.v4i2.195.

[6] I. Y. Supardi and A. Hermawan, Semua bisa menjadi programmer codeigniter basic. Elex Media Komputindo, 2018.

[7] R. Yesputra and N. Marpaung, "Pemodelan Aplikasi E-Skripsi Berbasis Arsitektur Mvc Pada Stmik Royal," Pemodelan Apl. E-Skripsi Berbas. Arsit., vol. 9986, no. September, pp. 45-50, 2018.

[8] J. Enterprise, HTML, PHP, dan MySQL untuk Pemula. Elex Media Komputindo, 2018.

[9] S. Aswati, M. S. Ramadhan, A. U. Firmansyah, and K. Anwar, "Studi Analisis Model Rapid Application Development Dalam Pengembangan Sistem Informasi," J. Matrik, vol. 16, no. 2, p. 20, 2017, doi: 10.30812/matrik.v16i2.10.

[10] Y. Apridiansyah and G. Gunawan, "Menggunakan Metode User Centered Design ( Ucd )," J. Technopreneursh. Inf. Syst., vol. 2, no. 2, pp. 74-80, 2019.

[11] U. Utariani and H. Herkules, "Monitoring Bimbingan Skripsi Online Pada Sekolah Tinggi Manajemen Informatika Dan Komputer (STMIK) Palangka Raya," J. SAINTEKOM, vol. 7, no. 1, p. 33, 2017, doi: 10.33020/saintekom.v7i1.19.

[12] B. W. Putra, A. Saputra, R. Sanjaya, and D. Kurniawan, "Implementasi Framework CodeIgniter dan Restful API pada 
JURNAL MEDIA INFORMATIKA BUDIDARMA

Volume 5, Nomor 3, Juli 2021, Page 838-847

ISSN 2614-5278 (media cetak), ISSN 2548-8368 (media online)

Available Online at https://ejurnal.stmik-budidarma.ac.id/index.php/mib

DOI 10.30865/mib.v5i3.3068

Sistem Informasi Manajemen Tugas Akhir,” Pros. Annu. Res. Semin. 2019, vol. 5, no. 1, pp. 978-979, 2019.

[13] R. Mahara and B. Basrul, "Perancangan Interface Aplikasi E-Skripsi Berbasis Android," Cybersp. J. Pendidik. Teknol. Inf., vol. 2, no. 2, p. 141, 2019, doi: 10.22373/cj.v2i2.4074.

[14] D. A. Kristiyanti and A. Mulyana, "Sistem Informasi Monitoring Skripsi Berbasis Web (Studi Kasus: Prodi Akuntansi Universitas Mercu Buana)," J. Sist. Inf. Bisnis, vol. 10, no. 1, pp. 56-63, 2020, doi: 10.21456/vol10iss1pp56-63.

[15] A. A. G. Y. Paramartha, I. G. M. Darmawiguna, N. K. Kertiasih, and R. W. Khoerniawan, "Sistem Informasi Pembimbingan Skripsi Online Berbasis Web (Studi Kasus: Ftk, Undiksha)," Proceeding Semnasvoktek, vol. 2, pp. 5664, 2017, [Online]. Available: http://eproceeding.undiksha.ac.id/index.php/semnasvoktek/article/view/734.

[16] J. Desember, M. Z. Faried, A. Mulwinda, and Y. Primadiyono, "Pengembangan Aplikasi Android Bimbingan Skripsi dengan Fitur Notifikasi," J. Tek. Elektro, vol. 9, no. 2, pp. 74-79, 2017, doi: 10.15294/jte.v9i2.10657.

[17] H. Sulistiono, S. Kom, and M. Kom, Coding Mudah dengan CodeIgniter, JQuery, Bootstrap, dan Datatable. Elex Media Komputindo, 2018. 